\title{
Investigation of biological condition of fish species in lower Ogun River wetlands, Lagos, Nigeria
}

\author{
Adetola JENYO-ONI ${ }^{1}$, Abbas Adebimpe HASSAN ${ }^{1 *}$ and Akeem Babatunde DAUDA ${ }^{2}$ \\ ${ }^{1}$ Department of Aquaculture and Fisheries Management, University of Ibadan, UI Post office, Ibadan, Nigeria. \\ ${ }^{2}$ Department of Fisheries and Aquacultural Technology, Federal University Dutsin-Ma, \\ P.M.B 5001, Dutsin-ma, Katsina State, Nigeria. \\ *Corresponding author, E-mail: abbasoau@gmail.com,Tel: +2348058482805
}

\begin{abstract}
The study was carried out to investigate the biological condition of fish species in lower Ogun River wetlands. A total of 175 individual fish belonging to 10 species were collected from artisanal fishermen using different types of fishing gears. Two biological indices; condition factor " $\mathrm{K}$ " and growth exponent " $\mathrm{b}$ " obtained from length-weight relationship were used to determine the biological condition of the fishes. The condition factor $(\mathrm{K})$ recorded during the study ranged between 0.55 in Liza grandisquamis and 5.61 in Oreochromis niloticus. The growth exponent (b) ranged from 1.48 in Penaus notialis to 5.67 in Gymnarchus niloticus. The regression coefficient of determination was significant for some of the fish with highest value of $\mathrm{R}^{2}=0.98$ for Sardinella madarensis. The study showed that most of the fish species in the study area are in poor biological condition and exhibit allometric growth.
\end{abstract}

(C) 2014 International Formulae Group. All rights reserved.

Keywords: Allometric growth, condition factor, growth exponent, length-weight relationship.

\section{INTRODUCTION}

Nigerian inland waters are generally experiencing decrease in fish yield due to reasons that may range from inadequate management of the fisheries to degradation of the water bodies (Odo et al., 2009). According to Ude et al. (2011), detail knowledge of the form and function of the river system and the response of fish species are needed for effective fisheries management planning. Knowledge of some quantitative aspects such as length-weight and condition factor $(\mathrm{K})$ or ponderal index of fisheries is an important tool for the study of fishing biology (Imam et al., 2010). Ayoade and Ikulala (2007) noted that in fisheries biology, length-weight relationship is very important as it can be used for estimation of average mathematical relationship between well being of the fish population. The condition factor $(\mathrm{K})$ in fish serves as an indicator (biological index) of physiological state of the fish in relation to its welfare. It has strong influence of biotic and abiotic environmental conditions and can be used as an index to assess the status of the aquatic ecosystem in which fish live (Anene, 2005). Thus, the condition factor is important in understanding the life cycle of fish species 
and it contributes to adequate management of these species, hence, maintaining the equilibrium in the ecosystem Imam et al. (2010). Ayoade and Ikulala (2007) also stated that length-weight relationship is of important application in stock assessment because it can be used in estimating the stock biomass and comparing of fish population from different regions. Such information may enhance management, conservation and culture of the fish species (Ude et al., 2011). The use of $\mathrm{K}$ for comparison is only adequate for fish of the same size (Blackwell et al., 2000), while allometric factor $b \neq 3$ is for fish of different ranges of length. A good number of researches have been carried out on lengthweight relationship of fish species in Nigeria. This includes Hannifer et al. (2006) on lengthweight relationship of Channa punctuta from western river, Ude et al. (2011) on fish species of Ebonyi river, Bala et al. (2009) on ichthyofauna of Daberam reservoir, Katsina, Imam et al. (2010) on four fish species of Wasai river Kano, among others. Most available works on length-weight relationship is on rivers, coastal water and reservoirs but little or no work is on the condition of fish species in wetlands, despite contribution of wetlands to fisheries resources in Nigeria. Wetlands serve as the link between water and land. They are transition zones where the flow of water, the cycling of nutrients, and the energy of the sun meet to produce a unique ecosystem characterized by hydrology, soils, and vegetation. Wetlands contribute to the national and local economies by producing resources (fish, fibre and water), enabling recreational activities and providing other benefits such as climate regulation, water purification, pollution control and flood protection (U.S.EPA, 2006). They also serve as sites for scientific research and education, and benefit commercial fishing (U.S.EPA, 2004). In Nigeria, wetlands are estimated to cover about $28,000 \mathrm{~km}^{2}$ which is about $3 \%$ of the $923,768 \mathrm{~km}^{2}$ land surface area of the country (Uluocha and Okeke, 2004). It is therefore important to study the physiological state of fish species in wetland which is an important aquatic ecosystem. This study was carried out to assess the length-weight relationship and biological indices (growth exponent and condition factor) of fish species in lower Ogun River wetlands with a view to investigating the biological condition of fish species in the study area.

\section{MATERIALS AND METHODS}

\section{Study area}

The study was carried out in lower Ogun River basin wetlands, (latitudes $6^{\circ} 33^{\prime}$ $6^{\circ} 38^{\prime} \mathrm{N}$ and longitudes $3^{\circ} 21^{\prime}-3^{\circ} 28^{\prime} \mathrm{E}$.) and it is a major wetland region in Nigeria, located in Ikorodu/Kosofe area of Lagos State (Tejuosho, 2006). The two major vegetation zones that can be identified on the watershed are the high forest vegetation in the north and central part and the swamp/mangrove forests that cover the southern coastal and flood plains, next to the lagoon.

\section{Collection and identification of fish samples}

Fish samples were collected at different landing sites within the wetlands between February and May 2013. The fish were caught by the artisanal fishermen through the use of gears such as gill nets, cast nets, traps of different sizes and shapes and identified to the lowest taxonomy level using the key prepared by Idodo-Umeh (2003) and Babatunde and Raji (2004).

\section{Parameter measurement and estimation of biological condition indices}

The length and weight of the individual fish species was measured in line with Abowei (2010). Estimation of the two biological indices Growth exponent (b) and Condition factor was done as stated below: The condition factor was estimated using $\mathrm{K}=$ $100 \mathrm{~W} / \mathrm{L}^{3}$. 
The growth coefficient (b) was estimated from $\mathrm{W}=\mathrm{aL}^{\mathrm{b}}$ which was transformed into natural logarithmic form $\log \mathrm{W}=\log \mathrm{a}+\mathrm{bLog} \mathrm{L})$.

Note: "W" is the weight of the fish in grams, " $\mathrm{L}$ " is the total length in centimeter, "a" is the constant, " $b$ " is growth exponent and " $\mathrm{K}$ " is the condition factor of the fish.

\section{Statistical analysis}

Simple descriptive statistics (mean and standard deviation) was used to present the data. The linear regression was done to determine the growth exponent " $b$ " and the constant "a" while the level of reliance of the "b" value was obtained from the significance level of the Regression coefficient $\left(\mathrm{R}^{2}\right)$. SPSS 17 was used for all the statistical analysis.

\section{RESULTS}

One hundred and seventy five individual fish species were reported during the study period. They comprised nine species of finfish from different families and one species of shellfish. Five of the finfishes were of primarily freshwater habitat while the remaining four are of marine origin and so also the shellfish. Chrysichthys nigrodigitatus and Oreochromis niloticus were the dominating species with 30 individual fish each while Sardinella madarensis was the least with just 11 individuals. The species had their mean total length ranging from $13.70 \pm 1.08 \mathrm{~cm}$ in Synodontis nigrita to $70.00 \pm 1.41 \mathrm{~cm}$ in Gymnarchus niloticus and means weights from 25.71 $\pm 0.95 \mathrm{~g}$ to1796 $\pm 63.75 \mathrm{~g}$ in Shilbe mystus and Gymnarchus niloticus respectively. The shellfish (Penaeus notialis) had the smallest weight and length which is incomparable with the finfishes (Table 1). $\mathrm{K}$ values for sampled fish species ranged from 0.55 (Liza grandisquamis) to 5.61 (Oreochromis niloticus). The growth exponent (b) ranged from 1.48 in P. notialis to 5.67 in G. niloticus. The coefficient of determination was significant $(\mathrm{P}<0.05)$ in $C$. nigrodigitatus, $P$. notialis, Acanthurus monroviae, Liza grandisquamis, Shilbe mystus, Sardinella madarensis with highest value of $\mathrm{R}^{2}=0.98$ (Table 1).

\section{DISCUSSION}

The occurrence of few species dominating may be due to the physicochemical parameters of the wetlands amongst which the salinity is very important because the ecosystem is a transit between freshwater and marine ecosystem and most marine species were recorded in the sampling site that is nearest to Lagos lagoon. Most species recorded have their length and weight with little deviation showing that the individual species were within close size range except in C. nigrodigitatus (length, $35.43 \pm 14.18 \mathrm{~cm}$ and weight $474.83 \pm 129.75 \mathrm{~g}$ ). This can be attributed to the type and size of gears used by the fishermen, however establishing that the fish caught did not cut across all the developmental stages and hence value of condition factor tend to be reliable (Abowei 2010). All the sampled species except $S$. nigrita fell outside the normal $\mathrm{K}$ factor stated by Imam et al. (2010), for proper growth and food utilization. This result suggested that the fish were not living well and it is similar to findings of Bala et al. (2009) in Daberam reservoir and Imam et al. (2010) in Wasai reservoir.

The $\mathrm{K}$ recorded for $P$. notialis is similar to the one recorded for the same range of size in Lagos lagoon by Lawal-are and Akinjogunla (2012). 
A. JENYO-ONI et al. / Int. J. Biol. Chem. Sci. 8(2): 705-710, 2014

Table 1: Biological indices of fish species in lower Ogun River wetlands.

\begin{tabular}{|c|c|c|c|c|c|c|}
\hline Family & Species & Length (cm) & Weight $(g)$ & Growth exponent (b) & $\begin{array}{c}\text { Coefficient of } \\
\text { determination }\left(R^{2}\right)\end{array}$ & $\begin{array}{l}\text { Condition } \\
\text { factor }(K)\end{array}$ \\
\hline Claroteidae & Chrysichthys nigrodigitatus $(F)$ & $35.43 \pm 14.18$ & $474.83 \pm 129.75$ & 4.52 & $0.53^{*}$ & 1.07 \\
\hline Gymnarchidae & Gymnarchus niloticus $(F)$ & $70.00 \pm 1.41$ & $1796.00 \pm 63.75$ & 5.67 & 0.06 & 0.58 \\
\hline Penaeidae & Penaeus notialis $(M)$ & $10.02 \pm 1.71$ & $11.62 \pm 3.39$ & 1.48 & $0.20 *$ & 1.15 \\
\hline Cichlidae & Oreochromis niloticus $(F)$ & $17.50 \pm 1.696$ & $308.00 \pm 44.37$ & 2.78 & 0.07 & 5.61 \\
\hline Mochokidae & Synodontis nigrita $(F)$ & $13.70 \pm 1.08$ & $108.00 \pm 7.39$ & 4.06 & 0.07 & 4.20 \\
\hline Acanthuridae & Acanthurus monroviae $(M)$ & $15.70 \pm 1.83$ & $45.70 \pm 6.24$ & 1.72 & $0.45^{*}$ & 1.18 \\
\hline Mugilidae & Liza grandisquamis $(M)$ & $27.00 \pm 1.58$ & $418.00 \pm 20.49$ & 5.00 & $0.38 *$ & 0.55 \\
\hline Schilbeidae & Shilbe mystus $(F)$ & $13.71 \pm 1.11$ & $25.71 \pm 0.95$ & 2.22 & $0.75^{*}$ & 1.03 \\
\hline Clupeidae & Sardinella madarensis $(M)$ & $20.00 \pm 1.00$ & $43.67 \pm 4.04$ & 1.67 & $0.98 *$ & 2.33 \\
\hline Haemulidae & Pomadasys jubelini (M) & $34.20 \pm 1.30$ & $930.00 \pm 44.72$ & 4.65 & 0.25 & 2.12 \\
\hline
\end{tabular}

*indicates $\mathrm{R}^{2}$ is significant at $\mathrm{P}<0.05$ 
The $\mathrm{b}$ value in $P$. notialis also revealed a negative allometric growth which is as well similar to the observation of Lawal-Are and Akinjogunla (2012) and contrary to the report of Yakubu and Ansa (2007) in Buguma creek, this position can be strengthened with observation of Prasad (2001) who stated that length-weight relationship of a species can be varied with locality and season. All the finfish have allometric growth $(b \neq 3)$ except for $O$. niloticus that has approximately isometric growth. While five of them have positive allometric, the others have negative allometric growth. Imam et al. (2010) also reported a similar result. The two biological indices for most species of fish in the ecosystem were not within the recommended level for fish with adequate nutrient utilization and optimum growth and similar to the conditions in many other water bodies with poor environmental conditions. Tejerina-Garro et al. (2005), noted that environmental factor influenced the biological condition of fish. This could be explained from the fact that anthropogenic activities which includes; sand-filling, sand mining, domestic and industrial waste disposal, land reclamation for bridges and building, going on in the area might have upset the wetland ecosystems for good living of fish species and other biotic components.

\section{Conclusion}

The length-weight relationship, growth exponent and condition factor has revealed that the lower Ogun River wetlands is in poor biological condition and this can be associated with poor environmental conditions, majorly due to anthropogenic activities. Therefore considering the importace of the wetland ecosystem, urgent attention should be given to the study area to save it from further destruction and probably total loss of an important ecosystem.

\section{REFERENCES}

Abowei JFN. 2010. The condition factor, Length - weight relationship and abundance of Ilisha africana (Block, 1795) from Nkoro River Niger Delta, Nigeria. Advance Journal of Food Science and Technology, 2: 6-11.

Anene A. 2005. Condition factors of four cichlid species of a man-made lake in Imo state, Southeast, Nigeria. Turk. J. Fish. Aquat. Sci., 5: 43-47.

Ayoade AA, Ikulala AOO. 2007. Length weight relationship, condition factor and stomach contents of Hemichromis bimaculatus, Sarotherodon melanotheron and Chromidotilapia guntheri (Perciformes: Cochlidae) in Eleiyele lake, South Western Nigeria. Rev. Biological Tropical, 55: 3-4.

Babatunde DO, Raji A. 2004. Field Guide to Nigerian Fresh Water Fishes ( $2^{\text {nd }}$ edn). Federal college of freshwater fisheries technology: New Bussa, Nigeria.

Bala U, Lawal I, Bolorunduro PI, Oniye SJ, Abdullahi SA, Bichi AH. 2009. Study of ichtyofauna of daberam reservoir in Katsina state. BAJOPAS, 2: 172-174.

Blackwell BG, Brown ML, Willis DM. 2000. Relative Weight (Wr) status and current use in fisheries assessment and management. Reviews in Fisheries Science, 8(1): 1-44.

Hannifer MA, Nagaraja M, Gopalakrisnan A. 2006. Length-weight relationship of Channa Punctuta (Bloch, 1793) from Western Ghats rivers of Tamil Nadu. Journal of Applied Ichthyology, 22(5): 463-467.

Idodo-Umeh G. 2003. Freshwater Fishes of Nigeria: Taxonomy, Ecological Notes, Diet and Utilization. Idodo Umeh Publisher: Benin, Nigeria.

Imam TS, Bala U, Balarabe ML, Oyeyi TI. 2010. Length-weight relationship and condition factor of four fish species from Wasai Reservoir in Kano, Nigeria. African Journal of General Agriculture, 6: $125-130$.

Lawal-Are AO, Akinjogunla VF. 2012. Penaeus notialis (Pink Shrimps): Lengthweight relationships and condition factor 
in Lagos lagoon, South West, Nigeria. Science and Technology, 2: 32-40.

Odo GE, Nwani CD, Eyo JE. 2009. The fish fauna of Anambra river basin, Mogeroa: Species abundance and morphometry. Revisita de Biological Tropical, 57: 177186.

Prasad G. 2001. Length - weight relationship of Penaeus monodon reared in semiintensive culture systems of Kerala, India. NAGA, ICLARM Q., 24: 16-17.

Tejerina-Garro F, Maldonado M, Ibañez C, Pont D, Roset N, Oberdorff T. 2005. Effects of natural and anthropogenic environmental changes on riverine fish assemblages: a framework for ecological assessment of rivers. Brazilian Archives of Biology and Technology, 48(1): 91108.

Tejuoso OJ. 2006. Wetland uses/dynamics for agricultural purposes and its health implications in lower Ogun River basin, Lagos, Nigeria. A technical report submitted to International Development Research Centre (IDRC) (ecosystem approach to human health team).
Ude EF, Ugwu LLC, Mgbenka BO, Nwani CD. 2011. Evaluation of length-weight relationship of fish species of Ebonyi River, Nigeria. Nigeria Journal of Fisheries, 8: 136-144.

Uluoch N, Okeke I. 2004. Implications of wetlands degradation for water resources management: lessons from Nigeria. GeoJournal, 61: 151-154.

USEPA (U.S. Environmental Protection Agency). 2004. Methods for evaluating wetland condition: wetlands classification. Office of water, U.S. Environmental Protection Agency, Washington, DC. EPA- 822-R-02-017.

USEPA. 2006. Application of Elements of a state water monitoring and assessment program for wetlands. Wetlands division, office of wetlands, oceans and watersheds, U.S. Environmental Protection Agency, Washington, DC.

Yakubu AS, Ansa EF. 2007. Length-weight relationships of the pink shrimp Penaeus notialis and giant tiger shrimp $P$. monodon of Buguma Creek in the Niger Delta Nigeria. The Zool., 5: 47-53. 